\title{
Semiotics of cultural history
}

\author{
Peeter Torop \\ Department of Semiotics \\ University of Tartu \\ Jakobi 2, 51014 Tartu, Estonia \\ e-mail: peeter.torop@ut.ee
}

\begin{abstract}
The interpretation of cultural history in the context of cultural semiotics, especially interpretation of semiotics of cultural history as a semiotics of culture, and semiotics of culture as a semiotics of cultural history, gives us, first, a deeper understanding of the analysability of cultural history and, at the same time, of the importance of history and different aspects of temporality for the semiotics of culture. Second, the history of the semiotics of culture, especially the semiotics of culture of the Tartu-Moscow School of Semiotics, is an organic part of cultural history, while the self-presentation of the school via establishing explicit and implicit contacts with the heritage of Russian theory (the Formalist School, the Bakhtin circle, Vygotskij, Eisenstein etc) was already a semiotic activity and an object of the semiotics of cultural history. Third, the main research object of semiotics of culture is the hierarchy of the sign systems of culture and the existent as well as historical correlations between these sign systems. Such conceptualization of the research object of semiotics of culture turns the latter into a semiotics of cultural history. Emphasizing the semiotic aspect of cultural history can support the development of semiotics of culture in two ways. First, semiotics of culture has the potential of conducting more in-depth research of texts as mediators between the audience and the cultural tradition. Second, semiotics of culture as a semiotics of cultural history can be methodologically used for establishing a new (chronotopical) theory of culture.
\end{abstract}

Keywords: semiotics of culture; history; text; chronotope; Juri Tynyanov; Mikhail Bakhtin; Juri Lotman; Boris Uspenskij

\section{Cultural semiotics and historical sources}

History of the Tartu-Moscow School of Semiotics as a part of cultural history is at same time an object of semiotics of cultural history. The Tartu-Moscow School had the mission to reconstruct the tradition and to recreate links with the forgotten or prohibited cultural and scientific achievements of the first decades of the 20th 
century. Its members made an effort to synthesize all of the crucial directions of theoretical thinking in the humanities: "Structural-semiotic literary criticism takes into consideration the experience of all preceding literary scholarship. It has, however, its own specific character. It arose in the environment of that scientific revolution that has marked the middle of the twentieth century and is organically connected with the ideas and methodology of structural linguistics, semiotics, information theory and cybernetics" (Lotman 1976: 16).

In 1972, using the same logic, Juri Lotman employed the term "the Russian School" to describe the international reception of Tynyanov, Propp, Bakhtin, Jakobson and other Soviet thinkers (Lotman 1972: 12). At the same time, Lotman also discovered a close relationship between the cultural and the scientific discourses in the Prague Linguistic Circle referred to as the Czech and Slovak School of Literary Studies. In his opinion, there is a close relationship between the type of culture and the respective type of general theory ("school"). In the following year, in 1973 the Theses on the Semiotic Study of Cultures (as Applied to Slavic Texts) collectively written by Lotman, Ivanov, A. Pyatigorskij, Toporov and Uspenskij were published. The last paragraph (9.1.0.) of this document that was missing from the English version of 1973 makes the following statement:

Scientific investigation is not only an instrument for the study of culture but is also part of its object. Scientific texts, being metatexts of the culture, may at the same time be regarded as its texts. Therefore any significant scientific idea may be regarded both as an attempt to cognize culture and as a fact of its life through which its generating mechanisms take effect. From this point of view we might raise the question of modern structural-semiotic studies as phenomena of Slavic culture (the role of the Czech, Slovak, Polish, Russian, and other traditions). (Lotman et al. 2013: 77)

Seen from a historical point view, the Tartu-Moscow School emerged as a synthesis of different schools and theories of the first decades of 20th century. It simultaneously constituted a direction in the humanities in general and in semiotics in particular. There are two models of historical developments in the context of semiotics of culture (for the international context of the history of cultural semiotics, see Torop 2015; Lorusso 2015). Firstly, seen from a narrower point of view, semiotics of culture appears as a result of a process rooted in Russian Formalism and progressing via the Prague Linguistic Circle, Roman Jakobson and the Tartu-Moscow School (Pilshchikov, Trunin 2016; Żyłko 2010). This viewpoint explains the general logic behind the emergence and development of thinking in semiotics of culture. Secondly, seen from a broader point of view the Tartu-Moscow School relies on the complex of what is known as Russian Theory. This idea had been implied in descriptions of the development of the 
Tartu-Moscow School well before it was clearly voiced by today's researchers. Also, the range of culture involved in Russian Theory can be broadened to include such scientific disciplines as cybernetics, information theory etc.

From the above it follows that Russian Formalism as a core scholarly experience for the development of the Tartu-Moscow School cannot be interpreted separately from the broader context of Russian Theory as such. Russian Theory itself can be evaluated only in terms of its processual development, similarly to how Russian Formalism can be seen going through several phases in its evolution within the complex of Russian Theory (Zenkin 2004: 8-9). Two attitudes towards Russian Formalism can be discerned in the framework of the Tartu-Moscow School. On the one hand, the new methods of linguistic-semiotic analysis relied on Russian Formalism, paying great attention to Viktor Shklovskij with the focus on his notion of 'device' ('priem'). Lotman called this direction the strategy of orientation towards formal semiotic analysis of simple research objects. It was supported in the Moscow part of the Tartu-Moscow School involving several structuralist linguists (Lotman 1991: 91). On the other hand, there existed the tendency to observe complex research objects. If the former trend was dominated by linguistic studies, the latter direction inspired investigations into literary studies and cultural semiotics. This also meant the becoming visible of Russian Formalism: first, the heritage of its initial stage; and, with the emergence of semiotics of culture, the later achievements from the evolution of Russian Formalism. The latter direction belonged to the St.Petersburg/Leningrad tradition and also included representatives of Russian Theory, e.g. Propp, Freidenberg, Bakhtin and others (Lotman 1991: 91).

Consequently, Lotman's and his colleagues' frequent references to Yurij Tynyanov and Roman Jakobson are deeply motivated. The disciplinary identification of semiotics of culture was formulated in the Theses of 1973 and can be described as a further development of Tynyanov's and Jakobson's interpretation of cultural dynamics. According to this programmatic text, semiotics of culture is "[...] the study of the functional correlation of different sign systems. From this point of view particular importance is attached to questions of the hierarchical structure of the languages of culture..." (Lotman et al. 2013: 53). In preparatory texts for the final version of the Theses certain key problems in the semiotic understanding of culture were discussed:

(a) Description of the place of some semiotic system in the general complex. It is easy to imagine studies such as: "The place of music as a semiotic system in the general system of culture"; "The place of mathematics in culture as a semiotic unity".

(b) Description of the influence of some particular semiotic system on others, i.e. "The role of painting in the semiotics of poetry of this or that era", "The role of cinema in the structure of the language of contemporary culture". 
(c) Analysis of the irregularity of the internal organization of culture. The existence of culture as a unitary organism seems to presuppose the existence of internal structural diversity. Investigating the phenomenon of intra-cultural polyglotism and the reasons for its necessity. (Lotman 2013a: 42)

Several concepts related to semiotics of culture that have gained new relevance against the background of culture's developmental dynamics are linked to one of the leading figures of Russian Formalism, Yurij Tynyanov. The fourth volume of Trudy po znakovym sistemam [Sign Systems Studies] is dedicated to Tynyanov, with the preface stressing the importance of his work which, in the opinion of the editors, "is directly related to the structural-semiotic analysis of cultural and literary texts" (Redkollegiya 1969: 5). In 1924, in his article "Literary fact" Tynyanov wrote: "Literary fact is heterogeneous, and in this sense literature is an incessantly evolving order" (Tynyanov 1977: 270). The concept of the literary order or system is very close to the notion of function:

A literary system is first of all a system of the functions of the literary order which are in a continuous interrelationship with other orders. [...] The evolution of the structural function occurs rapidly; the evolution of the literary function occurs over epochs; and the evolution of the functions of a whole literary system in relation to neighbouring systems occurs over centuries. (Tynyanov 1977: 277)

Literary order is just one functional order alongside with the order of everyday life, the order of culture, the social order. The study of literary evolution presupposes the investigation of connections first of all between the closest neighbouring orders or systems; a logical path leads from the structural to the literary function, from the literary to the verbal function. This logic follows from the position that "evolution is a change in the interrelationships between the elements of a system - between functions and formal elements" (Tynyanov 1977: 281). As predecessors to semiotics of culture, Tynyanov's works are also the source of the derivation of the idea of conceiving cultural artefacts through the dynamics of boundaries. A text can be defined in different ways: as a text in a certain language; as a representative of a literary genre; as an expression of a literary-historical style; as a social message; as an artistic text - in other words, it can be conceptualized and correlated with the cultural environment to different extents.

Tynyanov's system of orders is one of the sources of hierarchical understanding of culture and the system of cultural languages. Text is the central notion of semiotics of culture, and the early semiotics of the artistic text consisted of many elements from Russian Formalism as well as Russian Theory. Lotman's early semiotics of text and semiotics of culture can be considered as a synthesis of Tynyanov, Jakobson and Bakhtin. Thus, also the text is also a complex notion in semiotics of culture. The 
text as a whole comes into being at the point of contact of intra- and extratextual relations, which means that the text is a ternary whole: (1) it is made of some material (e.g. language is the material of literature); (2) the material is used in a specific way (artistic structure); (3) it emerges as a work in a cultural-historical context (the author's worldview, biography, influences etc). As a result, three different meanings emerge: subtextual, textual and functional. The meanings are based on the structure of the material, the text and the work, respectively. Structure is a hierarchical phenomenon and every hierarchy is based on a dominant. On the one hand, the structure of the text can be interpreted in comparison with the structure of the material (the material dominant) and the structure of the work (the functional dominant). On the other hand, the structure of the text can be described analytically as compositional (exposition, rising action, climax, falling action, resolution, etc.), architectonical (title, epigraph, prologue, chapters, epilogue, etc.) or narrative (plot, story). The last level consists in the poetics of the text or the conceptual artistic whole. Poetics is based on textual and intertextual specificity and proceeds from the conceptual value of the structural features of the text (Figure 1).

\begin{tabular}{|c|c|c|c|c|}
\hline & & \multicolumn{2}{|c|}{ TEXT } & \\
\hline LEVELS & \multicolumn{2}{|c|}{$\begin{array}{l}\text { INTRATEXTUAL RELATIONS } \\
\text { (MATERIAL) }\end{array}$} & \multicolumn{2}{|c|}{$\begin{array}{l}\text { EXTRATEXTUAL RELATIONS } \\
\text { (WORK) }\end{array}$} \\
\hline MEANING & $\begin{array}{l}\text { SUBTEXTUAL } \\
\text { (LINGUAL) } \\
\text { MEANINGS }\end{array}$ & \multicolumn{2}{|c|}{$\begin{array}{l}\text { TEXTUAL } \\
\text { MEANINGS }\end{array}$} & $\begin{array}{l}\text { FUNCTIONAL } \\
\text { MEANINGS }\end{array}$ \\
\hline STRUCTURE & $\begin{array}{l}\text { STRUCTURE OF } \\
\text { MATERIAL } \\
\text { (DOMINANT } \\
\text { ELEMENT OR } \\
\text { LEVEL) }\end{array}$ & \multicolumn{2}{|c|}{$\begin{array}{c}\text { STRUCTURE OF TEXT } \\
\text { (STRUCTURAL DOMINANT } \\
\text { OR FEATURE) }\end{array}$} & $\begin{array}{l}\text { STRUCTURE OF } \\
\text { WORK } \\
\text { (DOMINANT OF } \\
\text { RECEPTION) }\end{array}$ \\
\hline POETICS & $\begin{array}{l}\text { TEXTUAL } \\
\text { SPECIFICITY }\end{array}$ & \multicolumn{2}{|c|}{ POETICS OF TEXT } & $\begin{array}{l}\text { INTERTEXTUAL } \\
\text { SPECIFICITY }\end{array}$ \\
\hline
\end{tabular}

Figure 1. The construction of text. 
Figure 1 describes text construction. For a more detailed analysis of the poetics and the artistic point of view of the author it is important to see in the construction of text not only an organized space, but also a system of realities (worlds). Yet space does not exist without time, and the Bakhtinian heritage helps contemporary semiotics of culture in understanding culture and text as temporal-spatial (chronotopical) systems. The levels of chronotopes are also hierarchically organized, while the dominants can belong to time, space or timespace (chronotope). This is why, in order to obtain a holistic view of the text via its chronotopical system, it is important to establish an elementary typology of time and space as part of the chronotopical system that can be used to describe the respective features of the text (Figure 2).

\begin{tabular}{|l|l|l|}
\hline \multicolumn{3}{|c|}{ CHRONOTOPICAL SYSTEM } \\
\hline $\begin{array}{l}\text { TOPOGRAPHIC } \\
\text { REALITY (WORLD) }\end{array}$ & $\begin{array}{l}\text { PSYCHOLOGICAL } \\
\text { (REFLECTED) REALITY } \\
\text { (WORLD) }\end{array}$ & $\begin{array}{l}\text { METAPHYSICAL } \\
\text { (CONCEPTUALIZED) } \\
\text { REALITY (WORLD) }\end{array}$ \\
\hline $\begin{array}{l}\text { CONCRETE (SPECIFIC } \\
\text { LINEAR) TIME }\end{array}$ & $\begin{array}{l}\text { SUBJECTIVE (PERSONAL) } \\
\text { TIME }\end{array}$ & $\begin{array}{l}\text { MYTHOLOGICAL } \\
\text { (NONLINEAR) TIME }\end{array}$ \\
\hline $\begin{array}{l}\text { CONCRETE } \\
\text { (SPECIFIED) SPACE }\end{array}$ & $\begin{array}{l}\text { SUBJECTIVE (PERSONAL) } \\
\text { SPACE }\end{array}$ & $\begin{array}{l}\text { MENTAL (IMAGINARY) } \\
\text { SPACE }\end{array}$ \\
\hline HOMOPHONY & POLYPHONY & HETEROPHONY \\
\hline
\end{tabular}

Figure 2. Chronotopical system.

Bakhtin's manuscript heritage contains many fragments about different aspects of chronotope. His programmatic work concerning chronotope "Forms of time and of the chronotope in the novel" was in most part written in 1937-1938. "Concluding remarks" of the article were written in 1973 and the text as a whole was published posthumously. However, in 1970-1973 Bakhtin formulated various thoughts about chronotope in his notebook and on separate sheets of paper. The scheme of the chronotopical system given in Figure 2 is an attempt to synthesize this material so as to show that Bakhtin may possibly have had planned formulating a general theory of chronotope. Also, parallels can be found between Bakhtin's chronotopical and Lotman's structural understanding of text: compare Bakhtin's differentiation of architectonic time (chronotope) and compositional time of story or image (Bakhtin 2012: 506) to Lotman's construction of text. Also Lotman's intratextuality and extratextuality have parallels in the innerworld (chronotope as the environment of characters) and the outerworld (chronotope as the horizon of the author) of a text (Bakhtin 2012: 506). 


\section{Semiotics of culture and chronotopicality}

Disciplines concerned with the study of culture intersect on the level of methods and the language of description: the boundaries between philosophy of culture, sociology of culture, cultural studies and their sub-disciplines have become blurred. As a result, we can interpret the same problems from the vantage point of a diversity of disciplines and methods, proceeding from various aspects of the object of study, or the differing positions of scholars. Each culture functions as a whole, and the universal parameter and the basis of the wholeness of cultures is autocommunicativity. The functioning of culture as a system of education is also based on autocommunicativity. Methodologically, it is important that communicative and autocommunicative processes have two directions. First, communication is based on self-expression being creative and interesting. Second, one and the same culture can be understood as the culture of a (nation) state or of smaller interest groups who control and direct textual processes by controlling politics, ideology, marketing, the educational system and mass media.

Cultural experience is directly related to the way cultural languages are cultivated in a given society during a given historical period, as the richness of cultural languages is related to the increase of the multiplicity and richness of the culture's self-descriptive processes. Cultural experience exists in the cultural environment and cultural processes in this environement are the main research objects of disciplines studying culture:

Genetically speaking, culture is built upon two primary languages. One of these is the natural language used by humans in everyday communication. [...] The nature of the second primary language is not so obvious. What is under discussion is the structural model of space. (Lotman 1992a: 142)

First and foremost, Lotman had in mind textual space, yet time is also important in a textual space, as time and space constitute the two main analytical parameters of culture and research into culture and chronotope is a synthetical parameter. The chronotopical approach enriches both textual research and research into culture.

After having been introduced in Bakhtin's works, chronotopical analysis became particularly relevant again in connection with an interest in intersemiotic analysis. The latter's universality is manifested in its independence from the material in the structuring of texts and in making texts comparable. For example, intersemiotic translation of literature into film can be articulated and described more easily with the help of the concept of the chronotope (Torop 2000, 2013).

In Bakhtin's notes written in 1970-1971 a definite attempt to create a methodological framework for chronotopical analysis can be discerned: "Chronotopicality of thinking 
(especially ancient). A viewpoint is chronotopical, i.e. it embraces both the aspects of space and time. This is in direct relation with the axiological (hierarchical) viewpoint (attitude towards the high and the low). The chronotope of a depicted event, the chronotope of the narrator, and the chronotope of the author..." (Bakhtin 2002: 393). Understanding of chronotopical aspects of texts becomes the basis for a holistic analysis: "Consequently, every entry into the sphere of meanings is accomplished only through the gates of the chronotope" (Bakhtin 1981: 258).

A chronotopical analysis in principle distinguishes three levels in every text. The topographical chronotope is related to the story, the depiction of an event or a succession of events, the psychological chronotope expresses the viewpoints of the characters, and the metaphysical chronotope determines the conception of the text through the interrelations between the different chronotopical levels. Since the chronotopical levels are not related to the material of texts, this type of analysis is particularly rewarding in comparing texts consisting of different materials.

The word and the picture, narrative and performance, coexist implicitly or explicitly in every text. Chronotopical levels (Figure 3) display differences that exist in texts between the topographical storyworld as a reality, the individual worlds or the subjective perception of the world by the participants in the texts' events, and the conceptual world or the authorial synthesis of all aspects of text. The intersection between the vertical and horizontal levels is the sphere of semiotization.

\begin{tabular}{|c|c|c|c|}
\hline & & $\begin{array}{c}\text { SPHERE OF } \\
\text { SEMIOTIZATION }\end{array}$ & \\
\hline LEVELS & \multicolumn{2}{|c|}{$\begin{array}{l}\text { NARRATIVE } \\
\text { WORD }\end{array}$} & $\begin{array}{c}\text { PERFORMANCE } \\
\text { PICTURE }\end{array}$ \\
\hline $\begin{array}{l}\text { TOPOGRAPHICAL } \\
\text { CHRONOTOPE } \\
\text { HOMOPHONY }\end{array}$ & STORY & $\begin{array}{c}\text { STORYWORLD } \\
\text { INTERTEXTUALITY } \\
\text { MODEL OF REALITY }\end{array}$ & EVENTS \\
\hline $\begin{array}{l}\text { PSYCHOLOGICAL } \\
\text { CHRONOTOPE } \\
\text { POLYPHONY }\end{array}$ & NARRATION & $\begin{array}{l}\text { SELF AND OTHER } \\
\text { INNERWORLDS } \\
\text { MULTIMODALITY } \\
\end{array}$ & $\begin{array}{l}\text { PERFORMING } \\
\text { SHOWING }\end{array}$ \\
\hline $\begin{array}{l}\text { METAPHYSICAL } \\
\text { CHRONOTOPE } \\
\text { HETEROPHONY }\end{array}$ & $\begin{array}{l}\text { VERBAL } \\
\text { DESCRIPTION }\end{array}$ & $\begin{array}{c}\text { CONCEPTUAL WORLD, } \\
\text { PRINCIPLES } \\
\text { OF COHESION }\end{array}$ & $\begin{array}{l}\text { PICTORIAL } \\
\text { DEPICTION }\end{array}$ \\
\hline
\end{tabular}

Figure 3. Chronotopical levels of the text and the sphere of semiotization. 
Semiotization and semantization mean that on the topographical level of the chronotope, storyworld is simultaneously a world of signs - things, names, situations, behaviour. On the psychological level of the chronotope innerworld lies the world of the semiotic states, thoughts and words of the heroes; and on the metaphysical level of the chronotope's conceptual world is the world of the dominant themes of the author. Chronotopical analysis brings us closer to complex interpretation of text and its meaning-generating mechanism.

Chronotopical analysis does not equate to a comparison of the analyses of time and space: chronotope as a space-time necessarily introduces something additional. Chronotopical system is a toolbox for a better understanding of the individual poetics of authors and the holistic analysis of texts. Textual structure and chronotopical structure are two analytical parameters of the specificity of artistic texts. Every artistic text is an inherent part of cultural history, and the temporality of text can be described on the axis of synchrony - diachrony. The interpretation of a text as a multitemporal chronotopical whole where homochrony, polychrony and heterochrony coexist on the different levels of a text (of course, together with homothopy, polythopy and heterothopy) promises to be even more fruitful. Bahtin accentuated representational importance and significance of the chronotope (Bakhtin 1981: 250). In this context, not only the text, but also the author of the text becomes part of cultural history:

The author-creator moves freely in his own time: he can begin his story at the end, in the middle, or at any moment of the events represented without violating the objective course of time in the event he describes. Here we get a sharp distinction between representing and represented time. But a more general question arises: from what temporal and spatial point of view does the author look upon the events that he describes? [...] The represented world, however realistic and truthful, can never be chronotopically identical with the real world it represents, where the author and creator of the literary work is to be found. (Bakhtin 1981: 255, 256)

Just like language has a verbal and a visual side, also every literary text can be seen not only as storytelling, but also as performing and showing of events. Also the reception of literary texts or the existence of text in cultural memory are based on the correlation of retellings and performings (theatrical and filmic adaptations of literary texts, for example). The visuality of literary texts influenced early cinema as well. For Sergej Eisenstein, cinematographic montage was first used in literary texts (Tolstoy, Zola, etc.), but this montage had been understood by these authors mostly as narrative and temporal. Bakhtin's conception of chronotopes was the foreshadowing of a new type of montage. It was only at the beginning of the 21 st century that this type of montage was conceptualized by Lev Manovich: "Twentieth-century film practice has elaborated complex techniques of montage with different images replacing each other in time, but 
the possibility of what can be called a 'spatial montage' of simultaneously coexisting images has not been explored as systematically" (Manovich 2001: 323). In the context of this article it is important to accentuate the complementarity of temporal, spatial and chronotopical montage (there exist also other possibilities for using chronotope for studies of films, see Alexander 2007; Keunen 2010).

Filmic storytelling is just one example of the intermediality of contemporary culture, and the presence of intermediality is one of the reasons why textual and cultural analysis needs new tools. Tynyanov's understanding of literary and cultural dynamics, Lotman's semiotic theory of the text and Bakhtin's theory of the chronotope constitute a theoretical complex which can create new possibilities for developing both theoretical and empirical principles of cultural analysis. The last three sentences of Tynyanov's and Jakobson's manifesto "Problems in the study of language and literature" from 1928 can be interpreted as a historical introduction to the programme of the Tartu-Moscow School from 1973: "The question of a specific choice of path, or at least of the dominant, can be solved only through an analysis of the correlation between the literary series and other historical series. This correlation (a system of systems) has its own structural laws, which must be submitted to investigation. It would be methodologically fatal to consider the correlation of systems without taking into account the immanent laws of each system" (Jakobson 1985: 26-27). Jakobson's semiotic interpretation embedded in his model of communication from 1967 can be considered as the next implicit historical part of the programme of semiotics of culture:

The question of presence and hierarchy of those basic functions which we observe in language - fixation upon the referent, code, addresser, addressee, their contact or, finally, upon the message itself - must be applied also to the other semiotic systems. In particular, a comparative analysis of structures determined by a predominant fixation upon the message (artistic function) or, in other words, a parallel investigation of verbal, musical, pictorial, choreographic, theatrical, and filmic arts belongs to the most imperative and fruitful duties of the semiotic science. (Jakobson 1971: 621-622)

It is possible for the semiotics of culture after Lotman to develop its own disciplinary methodology based on the strength of the heritage from Russian Formalism and Russian Theory. The semiotic understanding of culture as a hierarchy of sign systems (cultural languages), on the one hand, and isomorphism of the individual and the culture as a collective personality, on the other hand, make the knowledge of historical sources important. One possibility of getting to know the sources is a systematic analysis of the terminological field, the history of metalanguage. A good example can be found in Lotman's definition of the text as he turns to the notions of the material and the work of art to describe the two sides of text (Lotman 1964: 59). Both notions 
were prominent concepts in the Formalist school (see Glossary 1977) and at the same time also very important notions for Russian Theory, especially for Bakhtin (Renfrew 2006). Not only early Lotman, but also the later author of Culture and Explosion could be more fruitfully read against the background of Formalism and Russian Theory, as the notion of the explosion implicitly appears in many authors of the 1920s. These possible sources for Lotman were not explicated in contemporary interpretation.

Another possibility for future development is the movement towards a semiotic science of culture. Tradition can be an innovative tool in this process. For example, the notion of the semiosphere stems from the dynamic nature of the notion of the text, and for Lotman movement from the notion of the text to that of semiosphere created closer contacts between space (textual, cultural, semiotic) and time (synchrony, diachrony, achrony). Lotman's last books are concerned with dynamics and processuality. However, the ambiguity in determining the boundary of the conceptual field of semiosphere (biosphere, social sphere, semiosphere, noosphere, semiotic space, semiosis) is a reason why the conceptual development of dynamism and processes is important. One possible development is the chronotopical analysis of text and chronotopical theory of culture.

\section{Cultural semiotics as semiotics of cultural history}

In his first book on semiotics, Lotman observed specific relations between history and text in the context of a new methodology. He hoped that understanding the nature of the structure of artistic text would facilitate the emergence of new research methods capable of analysing the complexity of the dynamic and multifactorial structure that is the cultural history of mankind (Lotman 1964: 12). In 1992, Lotman wrote in the foreword of Vol. 25 of Trudy po znakovym sistemam [Sign Systems Studies], the last volume to appear during his lifetime, that:

Semiotics has changed during the past decades. One of its accomplishments along its difficult path was its joining with history. The perception of history has become semiotic, and semiotic thinking has acquired historical features.

[...] The semiotic approach wants to avoid this conventional halting of the historical process. (Lotman 1992b: 3)

Lotman also concluded that "each generation has a language to describe yesterday, but in principle does not have one to describe tomorrow" (Lotman 1992b: 4). In 1998, in the epilogue to his study "The outlines of the prehistory and history of semiotics", Vyacheslav Ivanov, one of the pioneers of the semiotics of culture and founders of the Tartu-Moscow School, wrote: 
The task of semiotics is to describe the semiosphere without which the noosphere is inconceivable. Semiotics has to help us to orient ourselves in history. The joint effort of all those who have been active in this science or the whole cycle of sciences must contribute to the ultimate future establishment of semiotics. (Ivanov 1998: 792)

Semiotics of culture and (cultural) history were connected notions for the TartuMoscow School.

Already in 1971, Lotman and Boris Uspenskij defined culture through the notion of memory: "We understand culture as the nonhereditary memory of the community, a memory expressing itself in a system of constraints and prescriptions" (Lotman, Uspensky 1978: 213). In the same article they differentiated between the theoretical and processual aspects of memory. For the theoretical aspect, the key notions are 'text' and 'code': "Culture, as a mechanism for organizing and preserving information in the consciousness of the community, raises the specific problem of longevity. It has two aspects: (1) the longevity of the texts of the collective memory and (2) the longevity of the code of the collective memory" (Lotman, Uspensky 1978: 214). For the processual aspect, the key notions are 'hierarchy', 'remembering' and 'forgetting':

Considering culture as the long-term memory of the community, we can distinguish three ways in which it is filled. First, a quantitative increase in the amount of knowledge-filling the various nodes of the culture's hierarchic system with various texts. Second, a redistribution in the structure of the nodes resulting in a change in the very notion of "a fact to be remembered," and the hierarchic appraisal of what has been recorded in the memory; a continuous reorganization of the coding system which, while remaining itself in its own consciousness and conceiving itself to be continuous, tirelessly reforms separate codes, thus ensuring an increase in the value of the memory by creating "nonactual," yet potentially actualizable, reserves. Third, forgetting. The conversion of a chain of facts into a text is invariably accompanied by selection; that is, by fixing certain events which are translatable into elements of the text and forgetting others, marked as nonessential. In this sense every text furthers not only the remembering process, but forgetting as well. (Lotman, Uspensky 1978: 215-216).

In some of his late works Lotman used the differentiation between the internal and the external: internal communication and external communication, internal polyglotism and external polyglotism, and, what is most important in the context of this article, internal memory of culture and external memory of culture (Lotman 2000: 616; 1992a; for Lotman's conception of cultural memory in the context of contemporary memory studies, see Tamm 2015). In the context of polyglotism, the typological similarity of descriptions of text and culture should be borne in mind. In Universe of the Mind 
Lotman wrote about text: "Every text of a culture is by definition heterogeneous. Even in a strictly synchronic section the heterogeneity of the languages of culture forms a complex plurality of voices" (Lotman 1990: 103). In 1992 he concluded in the same vein about culture:

In actual history many dynamic yet non-synchronized processes, developing at different rates, exist alongside chronologically simultaneous processes, surviving the period of stability in other spheres of development. [...] Only in a heuristic can one isolate the history of literature, painting or some other type of semiotics from its surroundings. In reality, movement is realized as a continuous exchange the perception of alien systems, accompanied by their translation into a familiar language. (Lotman 2013b: 357, 367)

Both text and culture are elements of cultural history. Understanding of the nature of semiotics of culture is impossible outside cultural history and cultural history itself has, at the same time, a semiotic nature:

The study of the semiotic systems created by humanity over the course of its cultural history has led to the unexpected finding that these functions [i.e. the transmission of available information, the creation of new information, memory P. T.] are also characteristic of semiotic objects. In texts intended to communicate the first function predominates, while in artistic texts it is the capacity to generate new information. It has been established that a minimally functioning semiotic structure consists of not one artificially isolated language or text in that language, but of a parallel pair of mutually untranslatable languages which are, however, connected by a 'pulley', which is translation. A dual structure like this is the minimal nucleus for generating new messages and it is also the minimal unit of a semiotic object such as culture. Thus culture is (as a minimum) a binary semiotic structure, and one which at the same time functions as an indissoluble unit. (Lotman 1990: 2)

Explication of the semiotic aspect of cultural history can support the development of semiotics of culture in two directions. First, semiotics of culture has the potential for more thorough research of texts as mediators between the audience and the cultural tradition, and for studying how "a text fulfills the function of a collective cultural memory" (Lotman 1988: 55). Using the internal polyglotism of text is complementary to chronotopical analysis, especially if it is modified for the analysis of different forms of time in the structure of text. The temporality of text can be described as a complex of relations between homochrony, polychrony and heterochrony; while the main levels of temporality are the simultaneity of time, ambiguity of time and symbolicity of time (Figure 4). 


\begin{tabular}{|c|c|c|c|}
\hline & & $\begin{array}{c}\text { WORLD OF } \\
\text { HETEROCHRONY }\end{array}$ & \\
\hline LEVELS & \multicolumn{2}{|c|}{$\begin{array}{c}\text { WORLD OF } \\
\text { HOMOCHRONY }\end{array}$} & $\begin{array}{l}\text { WORLD OF } \\
\text { POLYCHRONY }\end{array}$ \\
\hline $\begin{array}{l}\text { TOPOGRAPHICAL } \\
\text { CHRONOTOPE } \\
\text { HOMOPHONY }\end{array}$ & $\begin{array}{l}\text { Historical } \\
\text { time (time } \\
\text { of events) }\end{array}$ & SIMULTANEITY & $\begin{array}{l}\text { Protohistorical } \\
\text { time (time of } \\
\text { historical sources) }\end{array}$ \\
\hline $\begin{array}{l}\text { PSYCHOLOGICAL } \\
\text { CHRONOTOPE } \\
\text { POLYPHONY }\end{array}$ & $\begin{array}{l}\text { Time of } \\
\text { characters }\end{array}$ & $\begin{array}{l}\text { AMBIGUITY } \\
\text { OF TIME }\end{array}$ & $\begin{array}{l}\text { Time of proto- } \\
\text { characters }\end{array}$ \\
\hline $\begin{array}{l}\text { METAPHYSICAL } \\
\text { CHRONOTOPE } \\
\text { HETEROPHONY }\end{array}$ & Profane time & $\begin{array}{l}\text { SYMBOLICITY } \\
\text { OF TIME }\end{array}$ & Sacred time \\
\hline
\end{tabular}

Figure 4. The temporal aspect of chronotopical analysis.

Second, semiotics of culture seen as semiotics of cultural history can be used for establishing a chronotopical theory of culture. The notion of textual chronotope can be methodologically changed into that of cultural chronotope. Then it will be possible to characterize culture as an environment on the level of the topographical chronotope, as self-description on the level of psychological chronotope, and as conceptual description on the level of metaphysical chronotope. The field of tension between cultural synchrony and diachrony is important on all the levels.

Semiotics of cultural history is a tool for the reconstruction of cultural-historical processes in textual polyglotism. Understanding texts and culture in the frame of semiotics of cultural history is oriented towards interpreting the relativity of the category of time. For today's researcher, semiotics of culture is an important predecessor of semiotics of (cultural) history:

Premises of the semiotics of history have been formulated on the grounds of cultural semiotics by scholars from the Tartu school. [...] Generally speaking, culture as memory is a semiotic system. Thus, it turns out that cultural semiotics, conceived from the beginning as the semiotics of memory, was also the path that led to semiotics of history. (Hałas 2013: 68, 69) 
Uspenskij was one of the first among those who described the difficulties of temporal analysis of texts and culture in the context of semiotics. He used the complementarity between time and space for historical analysis or for the analysis of phenomena (text, event) in the historical process. His thought was implicitly chronotopical, and for him, cultural history was, by default, a semiotics of cultural history (Uspenskij 1996). For Uspenskij, the past "is organized as the text readable in the perspective of the present" (Uspenskij 1996: 18). In his system the notion of "historical experience" has a central position which is very close to universal semiotic analysis of culture. In result we can say that Uspenskij's semiotics of history is in same time his semiotics of culture: "An analysis of Uspensky's concepts shows that semiotics of history forms an integral part of cultural semiotics; in other words, it does not represent some radical "historical turn" in this semiotical research program, but rather its logical extension" (Hałas 2013: 68).

This article highlighted but a single important aspect of the semiotics of cultural history. Interpretation of cultural history in the context of semiotics of culture, especially considering interpretation of the semiotics of cultural history as a semiotics of culture, and semiotics of culture as a semiotics of cultural history, gives us a more flexible understanding of cultural history and enables us to notice the complementarity between cultural history and history of culture (cf. Jewdokimow, Kizińska 2014: 94-95). History of the semiotics of culture, especially the semiotics of culture of the Tartu-Moscow School, is an inherent part of cultural history and the self-presentation of the school via revealing new explicit and implicit contacts with Russian Theory (the Formalist School, the Bakhtin circle, Vygotskij, Eisenstein etc); thus, it is an inherently semiotic activity as well as an object of the semiotics of cultural history. The humanities are, in principle, tools for interpretation of culture, and simultaneously part of the culture. The main research object of the semiotics of culture is the hierarchy of sign systems (cultural languages) of culture as well as the actual and historical correlation between these sign systems (languages). As the research object becomes thus conceptualized, semiotics of culture also becomes a semiotics of cultural history.

\section{References}

Alexander, Lily 2007. Storytelling in time and space: Studies in the chronotope and narrative logic on screen. JNT: Journal of Narrative Theory 37(1): 27-64.

Bakhtin, Mikhail 1981. Forms of time and of the chronotope in the novel. In: Bakhtin, Mikhail, The Dialogic Imagination: Four Essays. (Holquist, Michael; Emerson, Caryl, trans; Holquist, Michael, ed.) Austin: University of Texas Press, 84-258.

- 2002. Rabochie zapisi 1960 - nachala 1970 godov [Notes from the 1960s - the early 1970s]. In: Sobranie sochinenii v 7 tomah. T. 6. [Collected Works in 7 Volumes. Vol. 6.] Moscow: Russkie slovari, Yazyki slavyanskoj kul'tury, 371-439. 
- 2012. Formy vremeni i hronotopa $\mathrm{v}$ romane [Forms of time and of the chronotope in the novel]. In: Sobranie sochinenii $v 7$ tomah. T. 3. [Collected Works in 7 Volumes. Vol. 3.] Moscow: Yazyki slavyanskoj kul'tury, 341-511.

Glossary 1977. Formalist Theory. Glossary of Formalist Terminology. (Russian Poetics in Translation 4.)

Hałas, Elżbieta 2013. The past in the present: Lessons on semiotics of history from George $\mathrm{H}$. Mead and Boris A. Uspensky. Symbolic Interaction 36(1): 60-77.

Ivanov, Vyacheslav V. 1998. Ocherki po predistorii i istorii semiotiki. [The outlines of the prehistory and history of semiotics.] In: Izbrannye trudy po semiotike i istorii kul'tury. T. 1. [Selected Works on the Semiotics and History of Culture. Vol. I.] Moscow: Yazyki russkoj kul'tury, 605-811.

- 2013. Predislovie. In: Ivanov, Vyacheslav V. (ed), Russkij formalizm (1913-2013): Mezhdunarodnyj kongress $k$ 100-letiyu russkoj formal'noi shkoly. Tezisy dokladov. Moscow: Institut slavyanovedeniya RAN, 12-16.

Jakobson, Roman 1971. Linguistics in relation to other sciences. In: Selected Writings. II. Word and Language. The Hague: Mouton, 655-695.

- 1985. Verbal Art, Verbal Sign, Verbal Time. Minneapolis: University of Minnesota Press.

Jewdokimow, Dorota; Kizińska, Karolina 2014. Cultural Theory and History: Sign and Context. Poznań: Wydawnictwo Naukowe Wydziału Nauk Społecznych.

Keunen, Bart 2010. The chronotopic imagination in literature and film: Bakhtin, Bergson and Deleuze on forms of time. In: Bemong, Nele; Borghart, Pieter; De Dobbeleer, Michel; Demoen, Kristoffel; De Temmerman, Koen; Keunen, Bart (eds.), Bakhtin's Theory of the Literary Chronotope: Reflections, Applications, Perspectives. Gent: Academia Press, 35-55.

Lorusso, Anna Maria 2015. Cultural Semiotics: For a Cultural Perspective in Semiotics. Basingstoke: Palgrave Macmillan.

Lotman, Juri 1964. Lektsii po struktural'noj poetike. Vyp. I (Vvedenie, teoriya stiha). Trudy po znakovym sistemam [Sign Systems Studies] 1.

- 1972. Iskusstvoznanie i "tochnye metody" v sovremennyh zarubezhnyh issledovaniyah (Vstupitelnaya statya). In: Semiotika i iskusstvometriya. Moscow: Mir, 5-23.

- 1976. Analysis of the Poetic Text. Ann Arbor: Ardis.

- 1988. The semiotics of culture and the concept of a text. Soviet Psychology 26(3): 52-58.

- 1990. Universe of the Mind: A Semiotic Theory of Culture. London: I. B. Tauris \& Co.

- 1991. Zametki o tartuskih semioticheskih izdaniyah. Trudy po russkoj literature i semiotike tartuskogo universiteta 1958-1990: Ukazateli soderzhaniya. Tartu, 89-92.

- 1992a. Tekst i poliglotizm kul'tury [Text and cultural polyglotism]. In: Lotman, Juri, Izbrannye stat'i. Vol. 1. Stat'i po tipologii kul'tury. Tallinn: Aleksandra, 142-147.

- 1992b. Ot redkollegii (Editorial note). Trudy po znakovym sistemam [Sign Systems Studies] 25: 3-4.

- 2000. Pamyat' kul'tury. In: Lotman, Juri, Semiosfera. St. Petersburg: Iskusstvo-SPB, 614-621.

- 2013a. Proposals for the programme of the 4th Summer School on Secondary Modelling Systems. In: Salupere, Silvi; Torop, Peeter; Kull, Kalevi (eds), Beginnings of the Semiotics of Culture. (Tartu Semiotics Library 13.) Tartu: Tartu University Press, 41-43.

- 2013b. On the dynamics of culture. Sign Systems Studies 41(2/3): 355-370.

Lotman, Juri; Ivanov, Vjacheslav; Pjatigorskij, Aleksandr; Toporov, Vladimir; Uspenskij, Boris 2013. Theses on the semiotic study of cultures (as applied to Slavic texts). In: Salupere, Silvi; 
Torop, Peeter; Kull, Kalevi (eds), Beginnings of the Semiotics of Culture. (Tartu Semiotics Library 13.) Tartu: Tartu University Press, 53-77.

Lotman, Juri; Uspensky, Boris 1978. On the semiotic mechanism of culture. New Literary History 9(2): 211-232.

Manovich, Lev 2001. The Language of New Media. Cambridge: The MIT Press.

Pilshchikov, Igor; Trunin, Mikhail 2016. The Tartu-Moscow School of Semiotics: A transnational perspective. Sign Systems Studies 44(3): 368-401.

Redkollegiya 1969. Ot redaktsii. Trudy po znakovym sistemam [Sign Systems Studies] 4: 5-6.

Renfrew, Alastair 2006. A word about material (Bakhtin and Tynianov). The Slavonic and East European Review 84(3): 419-445.

Tamm, Marek 2015. Semiotic theory of cultural memory: In the company of Juri Lotman. In:

Kattago, Siobhan (ed.), The Ashgate Research Companion to Memory Studies. Farnham: Ashgate Publishing, 127-141.

Torop, Peeter 2000. Intersemiosis and intersemiotic translation. S: European Journal for Semiotic Studies 12(1): 71-100.

- 2013. The ideological aspect of intersemiotic translation and montage. Sign Systems Studies 4(2/3): 241-265.

- 2015. Cultural semiotics. In: Sharifian, Farzad (ed.), The Routledge Handbook of Language and Culture. London: Routledge, 170-180.

Tynyanov, Jurij 1977. Poetika, istoriya literatury, kino. Moscow: Nauka.

Uspenskij, Boris 1996. Izbrannye trudy. Vol. 1. Semiotika istorii. Semiotika kul'tury. Moscow: Yazyki russkoj kul'tury.

Zenkin, Sergej 2004. Vvedenie. In: Russkaya teorija: 1920-1930-e gody. Moscow: RGGU, 7-10. Żyłko, Bogusław 2010. Semiotyka kultury: Szkoła tartusko-moskiewska. Gdańsk: Słowo/obraz terytoria.

\section{Семиотика истории культуры}

Толкование истории культуры в контексте семиотики культуры, а особенно толкование семиотики истории культуры в качестве семиотики культуры и семиотики культуры в качестве семиотики истории культуры приближает нас прежде всего к возможности более глубокого понимания анализируемости истории культуры и в то же время и значения разных аспектов темпоральности для семиотики культуры. Во-вторых, семиотика культуры и особенно семиотика культуры Тартуско-московской школы, составляет естественную часть истории культуры, а самоопределение данной школы через явные и скрытые связи с цензурованной русской теорией (русская формальная школа, круг Бахтина, Выготский, Эйзенштейн и др) является по природе семиотической деятельностью и тем самым объектом исследования семиотики истории культуры. В-третьих, объектом исследования семиотики культуры является иерархия знаковых систем культуры и как актуальная, так и историческая корреляция между данными знаковыми системами. Подобная концептуализация объекта исследования превращает семиотику культуры одновременно в семиотику истории культуры. Актуализация семиотического аспекта истории культуры поддерживает развитие семиотики культуры в двух направлениях. С одной стороны, поддерживаются предпосылки семиотики 
культуры для более глубокого анализа текстов как посредников между аудиторией и культурной традицией. С другой стороны, семиотика культуры как семиотика истории культуры содействует методологически созданию новой (хронотопной) теории культуры.

\section{Kultuuriloo semiootika}

Kultuuriloo tõlgendamine kultuurisemiootika kontekstis, eriti kultuuriloo semiootika tõlgendamine kultuurisemiootikana ja kultuurisemiootika tõlgendamine kultuuriloo semiootikana, annab meile kõigepealt võimaluse sügavamalt mõista kultuuriloo analüüsitavust ja ühtlasi ajaloo ja temporaalsuse eri aspektide tähtsust kultuurisemiootikale. Teiseks moodustab kultuurisemiootika ja eriti Tartu-Moskva koolkonna kultuurisemiootika kultuuriloo orgaanilise osa ning selle koolkonna enesemääratlus nähtavate ja peidetud seoste kaudu tsenseeritud Vene teooriaga (vene vormikoolkond, Bahtini ring, Võgotski, Eisenstein jt) on loomuldasa semiootiline tegevus ja kultuuriloo semiootika uurimisobjekt. Kolmandaks, kultuurisemiootika uurimisobjektiks on kultuuriliste märgisüsteemide hierarhia ning tänapäevane ja ajalooline korrelatsioon nende märgisüsteemide vahel. Selline uurimisobjekti kontseptualiseerimise viis kultuurisemiootikas teeb sellest ühtlasi kultuuriloo semiootika. Kultuuriloo semiootilise aspekti esiletoomine toetab kultuurisemiootika kaht arengusuunda. Kõigepealt saab paremini avalduda kultuurisemiootika eeldus tekstide kui auditooriumi ja kultuuritraditsiooni vahendajate sügavamaks analüüsiks. Teiseks saab kultuurisemiootika kui kultuuriloo semiootika metodoloogiliselt kaasa aidata uue (kronotoobilise) kultuuriteooria loomisele. 